\title{
Ineffective Awareness of Islamic Banking Products as A Root Cause of Reluctance for the Same by Corporate Customers: A Case Study of MCB - NIB Merger in Pakistan
}

\author{
Dr. Zaeema Asrar Mohiuddin (Assistant Professor) \\ Rukhshinda Begum (M.phil Scholar) \\ Farheen Zehra Rizvi (M.phil Scholar) \\ Department of Commerce, University of Karachi, Pakistan
}

Doi: 10.19044/esj.2018.v14n13p134 URL:http://dx.doi.org/10.19044/esj.2018.v14n13p134

\begin{abstract}
This paper focuses on the lack of awareness as the major reason behind the reluctance of Corporate Customers towards Islamic Banking Products in Pakistan. Various reasons for avoiding the Islamic Banking products among customers are reflected in the literature reviewed. However, the need for further work analysis is required in the reviewed literature. Hence, the rationale for this study is to know the influence of unawareness about Islamic banking products among corporate customers and employees. This aspect was further explained through a case study. The case is based on the study of customers' reluctance in being a part of Islamic Banking Branches. This is because M-90 branches of Ex-NIB decided to become part of MCB Islamic after merger. Nevertheless, most of the corporate customers in these branches denied to associate with MCB Islamic, but rather preferred to become a part of Corporate Conventional Banking branches of MCB Bank. Results are extracted on the basis of a detailed review of literature and reviews from the industry experts. This study will be useful to understand reasons for this unwillingness that will provide us ways to avert any shortcomings if required in the products and services being provided by the Islamic Banks.
\end{abstract}

Keywords: Pakistan, Islamic Banking, Product Awareness, unwillingness, customers

\section{Introduction}

Islamic Banking has been proved to be the best ever growing sector in the world of finance. Besides Pakistan, Kuwait, Turkey, Malaysia, Behrain, Indonesia, Saudi Arabia, Qatar and United Arab Emirates are the major 
participants in the world of Islamic Banking. Existing demand inadequacy for Islamic Banking Products is anticipated to be the cause of strengthening the Islamic Banking Industry. Nevertheless, structured course of action for awareness in this area may have considerable impact on the products demand. Developing stage of the Islamic finance imply that its subsistence mainly depends on the understanding of the products and services being offered and the ease in their use. Besides, there is also the need to address the other barriers in its progress including limited number of branches at a few localities and the peoples' view point that Islamic Principles are not being followed by the Islamic Banks in their true sense. Another query about the Current Islamic Banking System is that this system is unable to provide true benefits of the Islamic Economics. Consequently, one of the challenges there is for the countries participating in the Banking Industry to adopt advanced business techniques for product development and awareness to retain their positioning and enhanced share in the banking industry.

\section{Islamic Banking Industry - Progress \& Market Share}

Appended below are the highlights of Islamic Banking Industry of Pakistan taken from the SBP Bulletin on Islamic Banking as of September 2017.

\begin{tabular}{|c|c|c|c|c|c|c|}
\hline \multirow[t]{2}{*}{ Particulars } & \multicolumn{3}{|c|}{ Track of Industry Progress } & \multicolumn{3}{|c|}{$\begin{array}{l}\text { Track of the Share in } \\
\text { Banking Industry of } \\
\text { Pakistan }\end{array}$} \\
\hline & Sep-16 & Sep-17 & Growth & Sep-16 & Sep-17 & $\begin{array}{c}\text { Grow } \\
\text { th }\end{array}$ \\
\hline $\begin{array}{c}\text { Total Assets (Rs. In } \\
\text { billions) }\end{array}$ & $1,788.00$ & $2,083.00$ & $16.50 \%$ & 11.80 & 11.90 & $\begin{array}{c}0.85 \\
\%\end{array}$ \\
\hline $\begin{array}{l}\text { Deposits (Rs. In } \\
\text { billions) }\end{array}$ & $1,476.00$ & $1,729.00$ & $17.14 \%$ & 13.30 & 13.70 & $\begin{array}{c}3.01 \\
\%\end{array}$ \\
\hline $\begin{array}{c}\text { Number of Islamic } \\
\text { Banking Institutions }\end{array}$ & 22.00 & 21.00 & & & & \\
\hline $\begin{array}{l}\text { Number of Islamic } \\
\text { Banking Branches }\end{array}$ & $2,226.00$ & $2,368.00$ & $6.38 \%$ & & & \\
\hline
\end{tabular}

It appears from the above detail that, however, the number of Islamic Institutions declined from September 2016 to September 2017. Nevertheless, Number of Islamic Banking Branches, Deposits, and Share of Assets in the Total Banking Assets showed a significant rise.

$>\quad$ Share of Punjab in Total Islamic Banking Branches in Pakistan is the highest i.e. $47.20 \%$ followed by Sindh i.e. $29.70 \%$. 


Percentage Share of the Financing Mix
\begin{tabular}{|c|c|c|c|}
\hline Types of Financing & Sep-16 & Sep-17 & Percentage Change \\
\hline Murabaha & 16.90 & 14.10 & -2.80 \\
\hline Ijarah & 7.80 & 8.30 & 0.50 \\
\hline Musharaka & 12.00 & 21.00 & 9.00 \\
\hline Diminishing Musharaka & 38.50 & 29.10 & -9.40 \\
\hline Salam & 3.30 & 3.80 & 0.50 \\
\hline Istisna & 7.00 & 6.20 & -0.80 \\
\hline Others & 14.50 & 17.50 & 3.00 \\
\hline Total & 100.00 & 100.00 & \\
\hline
\end{tabular}

The above detail of the Financing reflects that share of financing under Murabaha, Diminishing Musharaka, and Istisna declined in the Total Financing by the Islamic Banking branches.

\begin{tabular}{|c|c|c|c|}
\hline Client Wise Percentage Share in the Islamic Banking Industry \\
\hline Sector & Sep-16 & Sep-17 & Percentage Change \\
\hline Corporate Sector & 79.80 & 71.30 & -8.50 \\
\hline SMEs & 3.20 & 3.10 & -0.10 \\
\hline Agriculture & 0.70 & 0.50 & -0.20 \\
\hline Consumer Financing & 11.80 & 10.80 & -1.00 \\
\hline Commodity Financing & 2.80 & 12.30 & 9.50 \\
\hline Others & 1.70 & 1.90 & 0.20 \\
\hline Total & 100.00 & 100.00 & \\
\hline
\end{tabular}

Client wise position reveals that there is considerable decline in the share of Corporate Sector in Islamic Banking Industry from September 2016 to September 2017.

\section{Research Objective \& Scope}

This research is conducted to extract causes behind reluctance of Corporate Customers towards Islamic Banking. This is done such that the same could be addressed and settled to attain maximum benefit from the Islamic Banking Products.

\section{Research Hypothesis}

H1: Ineffective understanding of products and services being provided by Islamic Banks is a root cause of reluctance for the same by Corporate Customers

H0: Ineffective understanding of products and services being provided by Islamic Banks is not the reason for reluctance of the same by Corporate Customers 


\section{Literature Review}

Deasy Wulandari and Ari Subagio (2015) stated that Islamic Banking was started in Indonesia by the Financial Institutions in 1992. Muamlat was the First bank that started the application and implementation of Sharia principles and practices in Banking. This study states that the use of Islamic Banking or Conventional Banking depends upon the customer's perception regarding products and services being provided through both Islamic and Conventional Banks. Keria Kontot, Jamil Hamali and Firdaus Abdullah (2015) discussed the factors that influence customers' preferences to deposit money in Islamic banking. Moreover, this paper intends to discover the significant factors perceived as the most crucial driving forces influencing the customers' decision. This study explained that returns, sharia observance, self-belief and reliance, protection, flexibility, and transparency in withdrawal schemes were amongst the basic factors that have a significant impact on customers' decision. Security, zakat, and human touch were the additional elements found to be missing from the literature that will be addressed in future research studies.

Imam Buchari, Ahmad Rafiki and Mahmood Abdullah Hadi Al Qassab (2014) explain the level of knowledge in employees for Islamic Banking Products in Behrain. As per this study, well-aware and knowledgeable employees, possessing adequate understanding of the attributes of Islamic banking products, may attract customers towards Islamic Banking. It was stated that all the basis and principles related to Islamic Banking which are firmly stuck on the instructions given in the Quran and Sunnah should be figured out and practiced. Syed Ahmad Ali and Arif Hassan (2017) revealed the reasons behind misconceptions regarding Islamic Banking in Malaysia. This study is specified towards awareness of attitudes of employees for Islamic Banking concept and practices in Malaysia.

Consequently, Yvonne Saini, Geoff Bick and Loonat Abdulla (2011) studied the awareness of customers for the Islamic Banking products in South Africa. They suggested that Islamic Banks should identify the needs of their customers and develop the products according to the same. Naveed Azeem Khattak and Kashif-ur-Rehman (2010) opined that Shariah is the basis of Islamic Banking System where the element of interest is not acceptable. As per the findings of this study, customers do have the knowledge and understanding of Islamic Banking Products. However, these products do not meet their requirements and also lacks the features and attributes the customers want. This is the reason why customers move towards the Conventional Banking products for the specifications of banking products and services they need. Barathy Doraisamy, Arunagiri Shanmugam and Ravindran Raman (2011) explored the preferences of customers regarding products and services being offered by the Islamic Banks in Sungai. However, this study takes into consideration the business aspect of Islamic Banking besides religious 
concerns to gain market share in the area of services. Islamic Banking Industry is in its continuous efforts to gain the confidence of existing as well as prospective customers.

Hanudin Amin (2013) studied the deposit facilities that Islamic Banks in addition to the Conventional Banks are offering to customers in Malaysia and discussed discrepancies among the same. It is useful in providing an approach to the beginners and learners of Islamic Banking Industry and the deposit products they are providing. Ashfaq Ahmad, Rehmat ullah Awan and Imran Malik (2011) discussed the briefing of operational services and products being offered by Islamic banks with special consideration towards Pakistan. Besides the reflection of Islamic Banks performance in Pakistan, this paper provides support to the policy/ decision makers to discover ways they can maximize benefits from the use of Islamic Banking Products and Operations.

Keong Lee, Khor May Ling, Low Sheau Pey and Wong zi Hui (2012) focuses on the knowledge and view point of Non-Muslims regarding Islamic Banking products and services in Malaysia. Moreover, it helps the employees of Islamic Banks to device course of action to be a focus for more non-Muslim banking users. Level of responsiveness was analyzed based on the customers' demographics. Hence, the study also provides grounds for further research by including additional demographics.

Nain Tara, Madiha Irshad, Muhammad Rizwan Khan and MahwishYamin (2014) discuss the factors influencing the use of Islamic Banking facilities being provided by the banks of Pakistan. It was observed in the study that customers' preferences towards Islamic Banking are on the gradual rise. As per general understanding, religion is usually considered the top most consideration for preferring the products being offered by Islamic Banks. However, findings of the study under discussion do not prove the same. This is because of the customers' perception that Islamic Banks too are not providing the Shariah compliant services. Consequently, they prefer conventional banks if service standards of these banks are high and satisfactory for the customers. Haroon Rasheed and Muhammad Mudassar (2010) discussed the modern technique of Islamic Banking for the Agriculture sector of Pakistan. It focuses on the advantages of Bai Salam as it is not usually possible for the farmers to buy inputs with the cash. This study provides a brief overview of Islamic Banking evolution for the agriculture sector of Pakistan. It also produces two interest free advanced financing models that may be provided to the farmers. These two models are MAP and BOS models. Hence, these models have been presented with the objective to benefit both the farmers and the banks.

Hussain G. Rammal and Ralf Zurbruegg (2016) studied the awareness of Islamic financial products among Muslim population in Australia. They stated that the low use of the Islamic Financial Instruments among Muslims is 
due to the lack of relevant information towards Islamic Banking. Bakhita HGB (2017) discusses the link between Islamic Financing and the growth of economy. Six banks of different countries were taken into consideration for the stated objective. This study reflects the products where Islamic banks should reduce the amount of lending because these are playing negative role in the economic growth. However, it also clarifies that future studies should also be carried out on the stated matter to confirm the results of this study.

Khakan Najaf and Rabia Najaf (2016) discussed the history and development phases of the Islamic Banking in Pakistan. Their prime objective is to explain the influence of Islamic Banks on various economic indicators of Pakistan and ultimately to explore the relationship of Islamic Banking and the Economic progress. This study opens the door for further research in connection to the one made specifically for the focus on the awareness of technology that should be used to develop Islamic banking and the employee performance for the same. Muhammad Ashraf (2013) explains the reasons behind intensification of Islamic Banking in Pakistan. However, the State Bank of Pakistan is playing a vital role in this very important area. It is still an area to be studied and researched upon to take maximum advantage for the economic growth of Pakistan. This work is supposed to create grounds to formulate policies by the respective divisions or authorities in Pakistan and in the other developing countries of the world too.

\section{Research Methodology}

This study analyses impacts of Ineffective Communication of the Islamic Banking Products to the Corporate Customers that results due to lack of awareness and ultimately the reluctance for these products and services by these customers. This study is followed by a Case Study on the MCB-NIB Merger. Related literature is reviewed and interviews are conducted from the experts of different areas in MCB Bank and MCB Islamic Bank including the Product Division, Business/ Relationship Team, and the Operations Team. These experts were all selected to cover all major areas of the bank i.e. Operations, product development, and business. Analysis is based on the literature as well as on the analysts' opinions regarding the stated matter that helped us to get benefit of their specialized knowledge.

\section{Research Findings, Discussion and Conclusion}

Besides review of the literature, the following findings were gathered through the interviews/ meetings conducted from various Industry Experts.

From Division Head - Corporate Banking, MCB Bank Limited

He has elucidated various aspects and challenges that were faced and handled by MCB Bank in the process of merger. He considers the wide network of Islamic Banking Branches in Ex-NIB as an attraction for MCB to acquire NIB 
Bank. This consideration was based on the acquisition of a total of 170 branches. 90 of those (termed as M-90) were decided to be transferred in MCB Islamic, whereas 80 retail branches (termed as $\mathrm{R}-80$ ) were decided to be transferred in retail branches of MCB Conventional Banking. Nevertheless, in his valuable view and observation, most of the Corporate Customers in these branches seemed to be reluctant to continue their relationship with Islamic Bank due to the following reasons:

$>\quad$ Customers were convenient with the location of Corporate Branches in Ex-NIB.

$>\quad$ Majority of the customers is not very well aware of the core of Islamic Banking Products and their benefits.

Since the concept of Islamic Banking is established on Profit and Loss sharing, therefore, these may not provide a fix rate on their investment in bank; whereas Corporate Customers usually want a certain return to meet their financing requirements.

$>\quad$ Features of the Islamic Banking Products do not meet with their requirements of the Banking Products and Services to facilitate their business activities.

\section{Limited}

\section{From Branch Managers - Corporate Banking, MCB Bank}

One of the managers has the opinion that M-90 branches of Ex-NIB decided to become part of MCB Islamic Bank. However, initially, Corporate Customers in these branches are being moved to corporate branches of MCB Bank Limited. Later on, through an undertaking from their side, these will be moved to MCB Islamic Bank. Most of the customers in these branches seem to be the part of Islamic Banking except those to whom the Islamic Banking products and services do not suit as per their understanding.

While inviting to share the view point of another manager who has started his career with Islamic Banking and now is a branch manager in conventional banking, he is not so hopeful that corporate customers will end their relationship with conventional banking to move towards Islamic Bank. He expects that around 95\% corporate customers from M-90 branches will not be interested to choose Islamic Banking. This is because of the following reasons:

- $\quad$ They are the common customers of MCB and Ex-NIB and are already availing services and are satisfied in execution of their transactions with conventional branches of MCB.

- They have doubt whether Islamic Banking branches are truly compliant with Shariah.

- They have doubt if Islamic Banking is correct and conventional banking is not, and the reason conventional banking still continues. 
- Improper planning for this aspect at the time of merger process.

\section{From Regional Head - MCB Islamic Bank}

As per his views, customers are not well aware of the true concept of Islamic Finance or Islamic Banking. He has shared his recent experience with a Non-Muslim customer of Ex-NIB who was reluctant to join Islamic Banking. When he responded to the queries and fears related to the Islamic Banking, then the customer was convinced and he agreed willingly to get associated with the MCB Islamic. He clearly mentioned that Islamic Banking is not founded on the concept of earnings. Rather, customers and employees both move towards the same due to the principles. However, the following are a few highlights of correspondence between him and the customer when he visited them:

\begin{tabular}{|c|c|c|}
\hline Queries & $\begin{array}{c}\text { Customer Concerns } \\
\text { It is said that Islamic Banking is } \\
\text { based on Profit \& Loss sharing } \\
\text { means they may be required to bear } \\
\text { the loss too. }\end{array}$ & $\begin{array}{c}\text { Responses by the Bank Representative } \\
\text { How much profit rate are you getting } \\
\text { from the conventional? }\end{array}$ \\
\hline 1 & $2.50 \%$ & We do offer you the rate of 3.50\%. \\
\hline 2 & $\begin{array}{c}\text { Islamic Banking facility is designed } \\
\text { to facilitate Muslims. }\end{array}$ & $\begin{array}{c}\text { Equal rates are offered to all the } \\
\text { customers in Islamic Bank based on the } \\
\text { tier in which they lie according to their } \\
\text { deposit amount. }\end{array}$ \\
\hline
\end{tabular}

He said that up till 2022, Islamic Banks will capture 75\% market of Pakistan. Though, there are various strategies under development, however, growth is still continued and will surely meet the desired targets.

When he was asked about the KIBOR i.e. fixed in Islamic Banking as well, he responded that it is the law of the land i.e. required to be followed by the residents. However, as the development continues, the chances of the separate cost basis for Islamic Banks are there too.

When he was asked about whether all customers of M-90 branches of Ex-NIB are interested to be the part of MCB Islamic Bank, he responded that not all are interested and neither the MCB Islamic will be willing to acquire all. This is because of the negative spreads they were enjoying on their lending in Ex-NIB that may not be offered in Islamic Banking. The reason behind the same is that Investments by the Islamic Banks to generate profit are made in the Islamic modes at particular rates. Thus, whatever the profit or loss may be, it would be shared equally among the depositors as per the defined tiers.

In response to a question related to the different Shariah Advisors of the Islamic Banks, he said that all Islamic Banks are based on the similar concepts. Nevertheless, they are providing their services with different Shariah Advisors just because of their beliefs about Barelwi or Dewbandi. 
Conclusively, he is of the opinion that the people are not clear about the real concepts of Islamic Banking because of their improper communication. Thus, they do not come towards the same. However, once customers or employees get associated with the Islamic Banking, they usually do not move towards the conventional banking. He further stated that customers are convenient with conventional banking because the detail of investments is not shared with them and they suffer the loss only when the bank get bankrupt in case of investment in a business from where the same is not returned. However, this is not likely the case with Islamic Banks because both the profit and losses are shared gradually as and when they are earned/ suffered respectively. Though, conventional banks are operating since hundreds of years throughout the world, Islamic Banks have started operations since around 25 years back. Hence, they need considerable time to have the strong standing relative to the conventional Banks that requires strong and true communication by the Islamic Banking Representatives.

\section{From Area Manager - MCB Islamic Bank}

He has 13 years of banking experience and remained associated with both Conventional and Islamic Banking. As per his views about the Islamic Banking, he is more comfortable in Islamic Banking rather than that of the conventional. Though, he has better opportunities to avail at the conventional side too, however, he is not interested to move there after having true perspective of Islamic Banking. This is the reason that he is not only engaged in Islamic Banking and handling a high responsibility position, but he is also teaching the subjects related to Islamic Finance to better communicate the foundation, pillars, and the work around of the same.

\section{From Product Development Department in MCB Islamic Bank}

Appended below are the points addressed with and responded by a representative in the product development department:

\section{Some Details about Product Development Department}

This department is continuously engaged in the development of products that could satisfy the customers' requirements without the element of Interest. This is because they plan to lead the Islamic Banking Industry in Pakistan by 2020 .

\section{Brief Specifications of Islamic Banking Products being Offered to Corporate Clients \\ Four types of products are being offered by Islamic Banks: \\ 1. Trading Products \\ 2. Participating Products}


3. Rental Based Products

4. Services

\section{Market Share of Islamic Banks in the Overall Banking Industry $12 \%$}

\section{Is there any Risk of Default as no Lending is being provided by Islamic} Banks?

The risk may arise in case of trade where product is consumed whereas payment against the same is not made. To restrict such defaults, an undertaking/ promise for the self imposed penalty is committed by the customer at the time of agreement that is required to be paid by them in case of any default. Investment amount is converted into debt when default occurs and penalty is paid by the customer i.e. donated by the bank in charity. However, banks do not keep such earnings with them, but rather the same are donate by them in charity.

Main Difference between the Concepts of Islamic Banking and the Conventional Banking

\begin{tabular}{|c|c|}
\hline Islamic Banking & Conventional Banking \\
\hline Based on or Backed by Asset (Riba Free) & Interest Based \\
\hline $\begin{array}{c}\text { No concept of lending. However, any amount in } \\
\text { excess of the amount invested is to be treated as } \\
\text { charity }\end{array}$ & Interest is received on the money lent \\
\hline $\begin{array}{c}\text { Difference in Legal concept i.e. Separate } \\
\text { agreement for each and every aspect related to } \\
\text { transaction e.g. in case of Ijara, separate } \\
\text { agreement for the lease and separate for } \\
\text { purchase }\end{array}$ & \\
\hline
\end{tabular}

\section{Do you consider that Corporate Customers are Reluctant to Keep} Relationship with Islamic Banks? Why?

Yes, they are reluctant because they are not well aware of the legal and economic reality of economic banking products. If customers are communicated to properly and they too avoid being the critique rather focus on the positive aspects of Islamic banks, then there are high expectations of their shift towards Islamic banking. However, it needs considerable time and efforts to liberalize their thoughts and build up their trust.

Concluding the literature reviewed and interviews conducted from various experts of the Banking Industry who remained more or less linked with the MCB-NIB merger, the following reasons were identified to be the reason why customers get reluctant to retain relationship with the Islamic Banks: 
$>\quad$ Customers are not aware of the true concept of Islamic Banking/ Financing. Moreover, they are in doubt whether Islamic Banks in Pakistan are in actual complying with the Shariah principles.

$>\quad$ Some employees do not have the ability to deliver the idea of Islamic Banking in the sense that can convince the customers.

$>\quad$ Some features of Conventional Banking products like revolving credits are not available in Islamic Banking products. Hence, they do not come up with the desires of the customers.

$>\quad$ Locations of Islamic Banking branches are not so convenient for the customers.

\section{Suggestions}

Based on the above discussion and conclusion, the following measures are suggested that may help improve the awareness of Islamic Banking amongst customers:

$>\quad$ Knowledgeable employees staffed in Islamic Banks should have influencing sessions as guest speakers in various educational institutions.

$>\quad$ Effective training sessions should be held for the employees of Islamic Banks to guide them on how to convince customers and prospective customers for Islamic Financing.

$>\quad$ Some rewards should be announced for the employees who succeeded to have business from prospective customers.

\section{Limitation and Gap of the Study}

The above study is limited to the data collected and the time restraints. Moreover, resources required to proceed with the research procedure are scarce i.e. limited financial resources, accessibility to the desired personnel in data collection (for interviews) etc. Views of Corporate Customers, if obtained, may enhance the value of this study. However, they showed reluctance in sharing their views while tried to be contacted for a survey.

\section{References:}

1. Ahmad, A. (2011). An Overview of the Operations/Products offered by Islamic Banks in Pakistan. African journal of business management, 5(11), 4185-4190.

2. Akinsomi, O. (2012). Shariah compliant real estate development financing and investment in the Gulf Cooperation Council. Journal of Property Investment and Finance, 1-22.

3. Ali, S. A., \& Hassan, A. (2017). Employees' Attitude towards Islamic Banking: An Exploratory Study in Malaysia. International Research Journal of Social Sciences, 114-138. 
4. Amin, H. (2013). Some Viewpoints of Islamic Banking Retail Deposit Products in Malaysia. Journal of Internet Banking and Commerce, 114.

5. Buchari, I., Rafiki, A., \& Al Qassab, M. A. (2015). Awareness and attitudes of employees towards islamic banking products in Bahrain. 3rd Economics \& Finance Conference, Rome, Italy, April 14-17, 2015 and 4th Economics \& (pp. 68-78). London, UK: Elsevier Ltd.

6. Butt, I., Saleem, N., Ahmed, H., Altaf, M., Jaffer, K., \& Mahmood, J. (2010). Barriers to adoption of Islamic banking in Pakistan. Journal of Islamic Marketing.

7. Doraisamy, B., Shanmugam, A., \& Raman, R. (2011). A Study On Consumers' Perferences Of Islamic Banking Products And Services In Sungai Petani. Academic Research International, 1(3), 290-302.

8. HGB, B. (2017). Impact of Islamic Modes of Finance on Economic Growth through Financial Stability. Journal of Business \& Financial Affairs, 6(1), 1-7.

9. Islamic Banking Bulletin-September (2017). State Bank of Pakistan. (n.d.).

10. Khattak, N. A., \& Rehman, K. -U. (2010). Customer satisfaction and awareness of Islamic banking system in Pakistan. African Journal of Business Management, 662-671.

11. Kontot, K., Hamali, J., \& Abdullah, F. (2015). Determining Factors of Customers' Preferences: A Case of Deposit Products in Islamic Banking. 6th International Research Symposium in Service Management, IRSSM-6 2015, 11-15 (pp. 167-175). Kuching, Malaysia: Elsevier Ltd.

12. Ling, K. L., Ling, K. M., Pey, L. S., \& Hui, W. Z. (2012, April). Awareness Of Islamic Banking Products And Services Among NonMuslims In Malaysia. Malaysia.

13. Najaf, K., \& Najaf, R. (2016). Growth of Islamic Banking in Pakistan. Arabian Journal of Business and Management Review, 6(4), 1-6.

14. Rammal, H., \& Zurbruegg, R. (n.d.). Awareness Of Islamic Banking Products Among Muslims: The Case Of Australia. pp. 1-14.

15. Rasheed, H., \& Mudassar, M. (n.d.). Research on Innovative Models of Islamic Banking Product for Pakistani Farmers. Proceedings of the 7th International Conference on Innovation \& Management, (pp. 562567).

16. Riaz, U., \& Khan, N. (2017). An Islamic banking perspective on consumers' perception in Pakistan. Emerald Publishing Limited.

17. Saini, Y., Bick, G., \& Abdulla, L. (2011). Consumer Awareness And Usage Of Islamic Banking Products In South Africa. SAJEMS NS, 298-313. 
18. Samadani, D. E. (n.d.). Difference between Islamic And Conventional Banking. Al-Baraka Bank (Pakistan) Limited.

19. Tara, N., Irshad, M., Khan, M. R., \& Yamin, M. (2014). Factors Influencing Adoption of Islamic Banking: A Study from Pakistan. Journal of Public Administration and Governance, 4(3), 352-367.

20. (2016). World Islamic Banking Competitiveness Report 2016 New realities New opportunities. EY.

21. Wulandari, D., \& Subagio, A. (2015). Consumer Decision Making in Conventional Banks and Islamic Bank based on Quality of Service Perception. 2nd Global Conference on Business and Social Science2015, GCBSS-2015, 17-18 (pp. 471-475). Bali, Indonesia: Elsevier Ltd. 